\title{
SCHEME
}

\section{GENERAL HISTORICAL BIBLIOGRAPHIES}

(p. XIX)

\section{A}

\section{AUXILIARY SCIENCES}

(p. 1-10)

$\S 1$. Palaeography. 1-9. $-\S 2$. Diplomatics. 10-14. $-\S 3$. History of the book ( $a$. Manuscripts; $b$. Printed books). 15-77. $-\S 4$. Chronology. 78-84. $-\S 5$. Genealogy and family history. 85-109. $-\S 6$. Sigillography and heraldry. 110-116. $-\S 7$. Numismatics and metrology. 117-122.- § 8. Linguistics. 123-138. $-\S 9$. Historical geography, travels and discoveries. 139-198. $-\S 10$. Iconography and images. 199-214.

\section{B}

\section{MANUALS, GENERAL WORKS AND WORKS ON LARGE PERIODS}

\author{
(p. 11-31)
}

$\S 1$. Archives, libraries and museums ( $a$. Archives; $b$. Libraries; $c$. Museums). 215-246. - 2 . History of historiography and memory ( $a$. General; $b$. Special studies). 247-439. $-\S 3$. Methodology, philosophy, and teaching of history. 440474. $-\S 4$. Ethnology, folklore and historical anthropology. 475-493. $-\S 5$. General history. 494-554. $-\S 6$. Theory of the state and of society. 555-563. $-\S 7$. Constitutional and legal history. 564-571. $-\S 8$. Economic and social history. 572-619. $-\S 9$. History of civilization, sciences and education. 620-657. $-\S 10$. History of art. 658-667. $\S 11$. History of religions. 668-697. $-\S 12$. History of philosophy. 698-710. $-\S 13$. History of literature. 711-736.

\section{C}

\section{PREHISTORY}

(p. 33-39)

$\S$ 1. General. 737-747. - § 2. Palaeolithic and Mesolithic. 748-790. - § 3. Neolithic. 791-824. - § 4. Bronze age. $825-869$. $-\S 5$. Iron age. 870-893. 
D

THE ANCIENT EAST

(the Hellenistic states included)

(p. 41-51)

§ 1. General. 894-911. - § 2. The Near East. 912-938. - § 3. Egypt. 939-1041. - § 4. Mesopotamia. 1042-1092. $\S 5$. Hittites. 1093-1107. $-\S 6$. Jews and Semitic peoples to the end of the ancient world. 1108-1172. - § 7. Iran. 1173-1192.

\section{$\mathbf{E}$}

\section{GREEK HISTORY}

(p. 53-65)

$\S$ 1. Classical world in general. 1193-1205. - § 2. Prehellenic epoch. 1206-1237. - § 3. Sources and criticism of sources ( $a$. Epigraphical sources; $b$. Literary sources). 1238-1270. - $\S 4$. General and political history. 1271-1314. $\S 5$. History of law and institutions. 1315-1331. $-\S 6$. Economic and social history. 1332-1354. $-\S 7$. History of literature, philosophy and science ( $a$. Literature; $b$. Philosophy and sciences). 1355-1491. $-\S 8$. Religion and mythology. 1492-1509. - §9. Archaeology and history of art. 1510-1569.

\section{$\mathbf{F}$}

\section{HISTORY OF ROME, ANCIENT ITALY AND THE ROMAN EMPIRE}

(p. 67-83)

$\S 1$. The peoples of Italy. 1570-1589. - § 2. The Etruscans. 1590-1606. $-\S 3$. Sources and criticism of sources. (a. Epigraphical sources; $b$. Literary sources). 1607-1668. - §4. General and political history. 1669-1733. - § 5. History of law and institutions. 1734-1772. $-\S 6$. Economic and social history. 1773-1820. $-\S 7$. History of literature, philosophy and science ( $a$. Literature; $b$. Philosophy and science). 1821-1924. $-\S 8$. Religion and mythology. 19251953. $-\S 9$. Archaeology and history of art. 1954-2008. $-\S 10$. Late antiquity. Transformation of the Roman world. 2009-2036.

\section{G}

\section{EARLY HISTORY OF THE CHURCH TO GREGORY THE GREAT}

$$
\text { (p. 85-92) }
$$

$\S$ 1. Sources. 2037-2085. $-\S 2$. General. 2086-2102. $-\S 3$. Special studies. 2103-2211. - § 4. Hagiography. 22122218. 
H

\title{
BYZANTINE HISTORY
}

(since Justinian)

(p. 93-98)

§ 1. Sources. 2219-2254. - § 2. General. 2255-2264. - § 3. Special studies. 2265-2335.

\section{I}

\section{HISTORY OF THE MIDDLE AGES}

(p. 99-125)

$\S 1$. Sources and criticism of sources ( $a$. Non-literary sources; $b$. Literary sources). 2336-2376. $-\S 2$. General works. 2377-2406. - § 3. Political history ( $a$. General; b. 476-900; c. 900-1300; d. 1300-1500). 2407-2472. $\S$ 4. Jews. 2473-2482. $-\S 5$. Islam. 2483-2501. - § 6. Vikings. 2502-2511. - § 7. History of law and institutions. 2512-2553. - § 8. Economic and social history. 2554-2646. - 9 . History of civilization, literature, technology and education ( $a$. Civilization; $b$. Literature; $c$. Technology; $d$. Education). 2647-2713. - $\S 10$. History of art. 27142740. $-\S 11$. History of music. 2741-2744. $-\S 12$. History of philosophy, theology and science. 2745-2795. $\S 13$. History of the Church and religion ( $a$. General; $b$. History of the Popes; $c$. Monastic history; $d$. Hagiography; e. Special studies). 2796-2954. - § 14. Settlements. Place names. Town planning. 2955-2972.

\section{$\mathbf{K}$ \\ MODERN AND CONTEMPORARY HISTORY, GENERAL WORKS}

(p. 127-179)

$\S$ 1. General. 2973-3022. $-\S 2$. History by countries. 3023-4301.

\section{$\mathbf{L}$}

\section{MODERN AND CONTEMPORARY RELIGIOUS HISTORY}

\author{
(p. 181-195)
}

$\S 1$. General. 4302-4366. - § 2. Roman Catholicism ( $a$. General; $b$. History of the Popes; $c$. Special studies; $d$. Religious orders; $e$. Missions). 4367-4515. - § 3. Orthodox Church. 4516-4530. - § 4. Protestantism. 4531-4596. $\S 5$. Non-Christian religions and sects. 4597-4678. 


\section{$\mathbf{M}$ \\ HISTORY OF MODERN AND CONTEMPORARY CULTURE}

(p. 197-234)

$\S$ 1. General. 4679-4807. $-\S 2$. Academies, universities and intellectual organizations. 4808-4843. - § 3. Education. 4844-4911. $-\S$ 4. The Press. 4912-4995. $-\S 5$. Philosophy ( $a$. General, b. Special studies). 4996-5052. - § 6. Exact, natural, medical sciences and technique. 5053-5228. - § 7. Literature ( $a$. General; $b$. Renaissance; $c$. Classicism; $d$. Romanticism and after). 5229-5427. $-\S 8$. Art and industrial art ( $a$. General; $b$. Architecture; $c$. Sculpture, painting, etching and drawing; $d$. Decorative, popular and industrial art). 5428-5511. $-\S 9$. Music, theatre, cinema, photography and broadcasting. 5512-5588.

\section{$\mathbf{N}$ \\ MODERN AND CONTEMPORARY ECONOMIC AND SOCIAL HISTORY (p. 235-265)}

§ 1. General. 5589-5632. - § 2. Political economy. 5633-5642. - § 3. Industry, mining and transportation. 56435756. $-\S 4$. Trade. 5757-5820. $-\S 5$. Agriculture and agricultural problems. 5821-5861. $-\S 6$. Money and finance. 5862-5969. $-\S 7$. Demography and urban history. 5970-6049. $-\S 8$. Social history. 6050-6355. - § 9. Workingclass movement and socialism. 6356-6432.

\section{$\mathbf{O}$}

\section{MODERN AND CONTEMPORARY LEGAL AND CONSTITUTIONAL HISTORY} (p. 267-274)

$\S 1$. General. 6433-6443. - § 2. History of constitutional law. 6444-6462. - § 3. Public law and institutions. 64636483. - § 4. Civil and penal law. 6484-6591. - § 5. International law. 6592-6604.

\section{$\mathbf{P}$ \\ HISTORY OF INTERNATIONAL RELATIONS \\ (p. 275-311)}

$\S$ 1. General. 6605-6657. - § 2. History of colonization and decolonization (a. General; b. Asia; c. Africa; d. America; e. Oceania). 6658-6840. - § 3. From 1500 to 1789 (a. General; b. 1500-1648; c. 1648-1789). 6841-6910. - § 4. From 1789 to 1815 . 6911-6933. $-\S 5$. From 1815 to 1910. 6934-7011. $-\S$ 6. From 1910 to 1935. The First World War. 7012-7216. - § 7. From 1935 to 1945. The Second World War (a. General; b. Diplomacy. Economy; c. Military operations; d. Resistance). 7217-7332. - § 8. From 1945 (a. General; b. 1945-1956; c. From 1956). 7333-7539. 


\section{R}

\section{Asia}

(p. 313-320)

$\S$ 1. General. $-\S 2$. Western and central Asia. 7540-7546. - § 3. South Asia and Southeast Asia. 7547-7549. $\S$ 4. China. 7550-7652. - § 5. Japan (esp. before 1868). 7653-7705. - § 6. Korea. 7706-7709.

\section{S}

AFRICA

(esp. to its colonization)

(p. 321)

$\mathrm{N}^{\mathrm{os}} 7710-7719$.

\section{T}

AMERICA

(esp. to its colonization)

(p. 323)

$\mathrm{N}^{\mathrm{os}} 7720-7733$.

\section{U}

\section{OCEANIA}

(esp. to its colonization)

(p. 325)

$\mathrm{N}^{\mathrm{os}} 7734-7739$. 
